\author{
Attila Zsoldos
}

\title{
UGARSKA U DOBA SVETOG LADISLAVA
}

Attila Zsoldos

MTA BTK

Történettudományi Intézet

Budapest

\author{
UDK 94(439)"10" \\ 929.731 Ladislav \\ Izvorni znanstveni rad \\ Primljeno: 9.5.2018. \\ Prihvaćeno: 1.6.2020. \\ DOI: https://dx.doi.org/10.21857/yk3jwhxv39
}

Studija prikazuje stanje u Kraljevini Ugarskoj u razdoblju kralja Ladislava I. (1077. - 1095.), ali počinjući od 1063. kada se on pojavljuje na političkoj sceni. Prvi dio rada razmatra općenite karakteristike u zemlji. Drugi dio rada bavi se ustanovom dukata, čijom se uspostavom odražava karakterističan oblik razdiobe moći unutar vladajuće obitelji u drugoj polovini 11. stoljeća. Utvrđuje se da je dukat izvorno zauzimao područje jugoistoka i Transdanubije - i njima priključenih područja preko Drave kao i područje preko Tise oko Bihara. Sedamdesetih godina 11. stoljeća područje Njitre zamijenilo je ono oko Pečuha, a središte dukata seli se onda u područje Bihara.

Ključne riječi: Ladislav I. Arpadović (sv. Ladislav), dinastija Arpadovića, politička povijest, povijest 11. stoljeća, Njitra, Bihar, Pečuh, dukat (herceštvo)

Nepreciznost je ovog naslova, koja pred pozornim čitateljem zacijelo nije ostala nezamijećenom, dakako, namjerna. Sveti Ladislav jedan je od pripadnika dinastije Arpadovića koji su još i prije dolaska na prijestolje igrali značajnu ulogu u oblikovanju sudbine Ugarskog Kraljevstva, stoga bi u njegovu slučaju bilo neopravdano svesti "doba", koje je osobno obilježio, na godine u kojima je vladao kao kralj, kao i u slučaju većine kraljeva iz 13. stoljeća, poput Andrije II., Bele IV. ili Stjepana V. Dakle, u ovom radu pod nazivom "doba svetog Ladislava" podrazumijevam razdoblje između Ladislavova stupanja na političku scenu (1063.) i njegove smrti kao kralja (1095.), te ću posebno naznačiti ako to razdoblje svedem na doba vladavine svetog Ladislava.

U tako određenom razdoblju možemo utvrditi brojne pojave koje se mogu smatrati organskim nastavkom inicijativa pokrenutih u prvoj polovini 11. stoljeća, a ako su izvjesne promjene i vidljive, one ne prelaze okvire zadane $u$ prethodnom razdoblju. Međutim, među tim promjenama ima ponekih koje naznačuju nove smjerove. 
S gledišta političke povijesti to se razdoblje dijeli na dva izričito zasebna dijela, čija se granica može smjestiti upravo u 1077. godinu, kad sveti Ladislav stupa na prijestolje. Prvi dio obilježen je nesređenim okolnostima koje su nastupile nedugo nakon smrti svetog Stjepana. Između 1041. i 1074. u Ugarskom Kraljevstvu došlo je do šest smjena vladara, od kojih je svaka dovela do nasilnih događaja, većinom uz uplitanje inozemnih vlasti. Političku stabilnost ponovno je uspostavila gotovo dvadesetogodišnja vladavina svetog Ladislava, međutim, ona nije bila konačna u svakom pogledu. ${ }^{1}$

Naspram rastezljive naravi političkih odnosa, strukture koje su izgradile Ugarsko Kraljevstvo pokazuju se iznenađujuće čvrstima, što uvjerljivo svjedoči o učinkovitosti organizacije države svetog Stjepana. Što se tiče kraljevske časti uočljivo je da se po pitanju nasljeđivanja prijestolja pouzdano može utvrditi jedno jedino pravilo: vladar mora potjecati iz dinastije Arpadovića. U slučaju više kandidata, različita načela nasljeđivanja najviše su imala ulogu $u$ načelnom utvrđivanju pretenzija na prijestolje, no o samom pitanju odlučivali su onodobni odnosi moći. Bazilika koju je sveti Stjepan osnovao u Stolnom Biogradu ${ }^{2}$ u tom se razdoblju već može smatrati sakralnim središtem dinastije. $U$ to se vrijeme javlja samo kao mjesto krunidbe, $^{3}$ a za mjesto pokopa kraljevi iz 11. stoljeća odabirali su različite crkve, te je nasljednik svetog Ladislava, kralj Koloman, ponovno izabrao baziliku u Stolnom Biogradu za svoje vječno počivalište. ${ }^{4}$ Identifikacija nakita rabljenog pri krunidbi $\mathrm{u}$ tom razdoblju nije moguća, sigurno je samo da je danas poznati donji dio Svete krune, corona Graeca, dospjela u zemlju u vrijeme vladavine Gejze I., starijeg brata Ladislava Svetog, kao poklon bizantskoga cara Mihajla VII. ${ }^{5}$

Podanici su od kralja očekivali da svoju vlast osobno provodi, osobito na polju pravosuđa i vojnog zapovjedništva. S tim u skladu s jedne je strane središte vlasti bio kraljevski dvor koji je činila vladareva neposredna okolina, a s druge strane to središte nije bilo vezano za mjesto, već je djelovalo ondje gdje je kralj u to vrijeme boravio. Tako među poznatim boravištima Ladislava Svetog koji je već vladao kao kralj nalazimo Ostrogon ${ }^{6}$ - koji je, slično Stolnom Biogradu, od svih gradova u zemlji bio najbliži tome da ga smatramo vladarskim sjedištem - kao i jedan od kraljevskih

1 Opći pregled tog razdoblja vidi u Pál Engel, The Realm of St. Stephen. A History of Medieval Hungary, 895-1526, London - New York 2001., str. 25-34.

2 Chronici Hungarici compositio saeculi XIV, c. 66, prir. Alexander Domanovszky, Scriptores rerum Hungaricarum tempore ducum regumque stirpis Arpadianae gestarum, sv. 1-2, prir. Emericus Szentpétery, Budapest 1937.-1938. (dalje SRH) 1, str. 316.

3 Chronici Hungarici compositio saeculi XIV, cc. 86, 94, 97; SRH 1, str. 343, 358, 361.

4 PálEngel, Temetkezések a középkoriszékesfehérváribazilikában [Sahranjene osobeu stolnobiogradskoj srednjovjekovnoj bazilici], Századok, sv. 121, Budapest 1987., str. 613-637.

5 Ferenc Makk, Magyar külpolitika, 896-1196 [Ugarska vanjska politika, 896. - 1196.]. Szeged 1996. ${ }^{2}$, str. 103-104.

6 Cosmae Pragensis Chronica Boemorum, Lib. II., c. 41, prir. Bertold Bretholz, Monumenta Germaniae Historica. Scriptores Rerum Germanicarum, Nova series II, Berolini 1923., str. 146. 
vladarskih dvorova, Dömös ${ }^{7}$ u blizini Ostrogona ili upravo Bodrog, ${ }^{8}$ središte jedne od županija koje državu dijele na manje administrativne cjeline.

Kraljevski je dvor bio dvojaka značaja: dijelom je organizirao svakodnevni život vladara, a dijelom je bio dom najviše razine vladajućeg sloja, jer su tu redovito boravili obnašatelji najviših crkvenih i svjetovnih časti koji su tvorili Kraljevsko vijeće. Vladara načelno ništa nije obvezivalo na to da prihvati dobiveni savjet, no to je u praksi bilo svrhovito jer je po općem shvaćanju Vijeće predstavljalo "zemlju". ${ }^{9}$ Vijeće je donosilo odluke koje su propisivale opće norme koje danas nazivamo zakonima, na što ukazuje i jedan od članaka zbirke zakona poznate pod nazivom III. zakona svetog Ladislava, ${ }^{10}$ povremeno uključujući među sudionike sjednica velikaše koji u tom trenutku ne obnašaju čast, kao što se to dogodilo u slučaju II. zakona Ladislava Svetog. ${ }^{11}$

U razdoblju vladavine Ladislava Svetog tekao je žustar zakonodavni rad, no u pitanju vremena nastanka zakona sačuvanih pod kraljevim imenom moramo se suočiti s brojnim poteškoćama. Kod sva tri takozvana zakona možemo smatrati pouzdanim da su svoj danas poznati oblik poprimili nakon naknadna uređivanja, to jest da tekstovi zapravo zapisuju odluke donesene na različitim mjestima i $\mathrm{u}$ različito vrijeme, za što u sva tri slučaja nalazimo jasne tragove. Situaciju dalje zamršuje činjenica da - kao što je poznato u relativno širokom krugu - o tekstu koji se naziva "III. zakonom svetog Ladislava" jedna struja unutar znanstvenog istraživanja sumnja da njegove odredbe dijelom ili u cjelini potječu iz vremena prije stupanja Ladislava Svetog na prijestolje 1077. godine. Međutim, mišljenja se razilaze o tome je li u tom smislu opravdano uzeti u obzir razdoblje između 1063. i 1074., odnosno 1074. i 1077., to jest doba vladavine Salomona ili Gejze I. Da bi zbrka bila potpuna, unutar te struje poznato je i stajalište koje ni kod III. zakona, koji se, dakle, vremenski smješta prije 1077., ne isključuje mogućnost da sadrži nekoliko odredaba nastalih u doba Ladislavove vladavine, no ujedno spominje i da tekst II. zakona, za koji svi ostali istraživači tog pitanja smatraju da potječe iz doba vladavine Ladislava Svetog, može sadržavati odredbe donesene u godinama kraljevanja Gejze I. ${ }^{12}$

7 (1079.): Diplomata Hungariae antiquissima, accedunt epistolae et acta ad historiam Hungariae pertinentia I. Ab anno 1000 usque ad annum 1131, prir. Georgius Györffy et al., Budapest 1992. (dalje: DHA 1), str. 225-226.

Chronici Hungarici compositio saeculi XIV, c. 139 (SRH 1, str. 417).

9 József Gerics, A korai rendiség Európában és Magyarországon [Rani feudalizam u Europi i Ugarskoj], Budapest 1987., str. 265-270.

10 Sancti Ladislai decretorum liber tertius, c. 15.: regis et principum decreta; Levente Závodszky, A Szent István, Szent László és Kálmán korabeli törvények és zsinati határozatok forrásai. Függelék: A törvények szövege [Izvori zakona sv. Stjepana, sv. Ladislavi i Kolomana i sinodalnih zaključaka iz njihovog vremena. Dodatak: Tekst zakona], Budapest 1904. (reprint: Pápa 2002.), str. 177, The Laws of the Medieval Kingdom of Hungary vol. 1. 1000-1301, prir. János M. Bak - György Bónis - James Ross Sweeney, Bakersfied 1989. (dalje: LMKH), str. 21.

11 Sancti Ladislai decretorum liber secundus, (praefatio), Závodszky, Törvények és zsinati határozatok, str. 166; LMKH, str. 12.

12 Sve to podrobnije, vidi: Monika Jánosi, Törvényalkotás a korai Árpád-korban [Zakonodavstvo u ranom razdoblju Arpadovića], Szeged 1996., str. 104-128. 
Za cijelo je doba Arpadovića karakteristično shvaćanje po kojem je isključivi nositelj i izvor svjetovne vlasti kralj: svatko drugi može imati vlast koja prelazi granice vlastitih posjeda ako mu kralj prepusti dio svoje vlasti. Karakterističan oblik podjele vlasti unutar vladarske kuće u drugoj polovini 11. stoljeća jest praksa po kojoj bi kralj trećinu zemlje prepustio na upravljanje bratu ili bratiću koji nosi naslov hercega. Tako uspostavljeni ducatus, koji je u unutarnjopolitičkim sukobima toga doba povećavao izglede pretendenta na prijestolje, konačno je ukinuo kralj Koloman na prijelazu iz 11. u 12. stoljeće. ${ }^{13} \mathrm{Na}$ pitanje dukata vratit ću se na kraju ovog rada.

Osnovna institucija državne uprave bila je županija. ${ }^{14}$ Stup županije činilo je pojedino specifično kraljevsko vlastelinstvo, županat (lat. comitatus castri, mađ. várispánság). Županat se sastojao od utvrde - izgrađene od zemljanih šanaca koji su u 11. i 12. stoljeću bili utvrđeni uglavnom drvenom konstrukcijom $-{ }^{15}$ i pripadajućih zemljoposjeda, koji su služili izdržavanju utvrde, odnosno služinskog puka pod teretom raznovrsnih obveza, koji je na njima živio. Ti posjedi nisu tvorili posve kompaktne teritorijalne blokove, pa je tako lanac zemljišta utvrde ocrtavao granice nadležnosti utvrde te je cjelovitu županiju činilo područje unutar tih granica. Dakle, županija nije bila neovisna o županiji utvrde, no nije bila ni istovjetna s njom, jer je njezino područje obuhvaćalo i crkvene i privatne posjede unutar njegovih granica. Župan na čelu županata bio je ujedno i župan koji je upravljao županijom. Organiziranje prvih županija odvijalo se na prijelazu iz 10. u 11. stoljeće, ${ }^{16}$ no sigurno je da su nove županije nastale i u vrijeme svetog Ladislava: tako se, primjerice, županija Kolon, koja je 1009. još obuhvaćala područja kasnije nastalih županija Zale i Šomođ (mađ. Somogy), do 1061. već sigurno raspala na samostalne Zalu i Somogy, ${ }^{17}$ te se poslije to stanje ustalilo.

Organiziranje crkve također se razvijalo prethodno naznačenim putom, premda su se ti događaji grupirali isključivo u vrijeme vladavine svetog Ladislava, što zacijelo

13 Sažeti prikaz institucije dukata, vidi: György Györffy, A magyar nemzetségtől a vármegyéig, a törzstől az országig [Od ugarskog plemićkog roda do županije, od plemenskog saveza do države], Századok, sv. 92, Budapest 1958., str. 47-87, 565-595, Gyula Kristó, A XI. századi hercegség története Magyarországon [Povijest herceštva u Ugarskoj u 11. st.], Budapest 1974., odnosno u novije vrijeme Dániel Bagi, Új közelítési lehetőségek a 11. századi hercegség történetének vizsgálatához [Novi pristupi proučavanju povijesti herceštva u 11. stoljeću], u: Hercegek és hercegségek a középkori Magyarországon [Hercezi i herceštva u srednjovjekovnoj Ugarskoj], ur. Attila Zsoldos, Székesfehérvár 2016., str. 25-57.

14 Gyula Kristó, A vármegyék kialakulása Magyarországon [Formiranje županija u Ugarskoj], Budapest 1988.

15 Maxim Mordovin, A várszervezet kialakulása a középkori Magyarországon, Csehországban és Lengyelországban a 10-12. században [Formiranje sustava tvrdih gradova u srednjovjekovnoj Ugarskoj, Češkoj i Poljsko u razdoblju od 10. do 12. stoljeća], Budapest 2016.

16 Attila Zsoldos, Szent István vármegyéi [Županije sv. Stjepana], u: Államalapitás, társadalom, múvelődés [Izgradnja države, društvo, kultura], ur. Gyula Kristó, Budapest 2001., str. 43-54.

17 1009.: (DHA 1, str. 52), 1061. (DHA 1, str. 171). Za tumačenje podataka vidi Attila Zsoldos, Somogy megye kialakulásáról [O formiranju županije Šomođ], u: A honfoglaló magyarság állama, kultúrája és az ósi vastermelés [Država, kultura i drevna metalurgija Mađara u doba doseobe u Ugarsku], Somogyfajsz 1998., ur. Imre Stamler, Dunaújváros 1998., str. 37-50. 
nije neovisno o spomenutoj političkoj stabilnosti karakterističnoj za to doba. ${ }^{18}$ Između novih benediktinskih samostana šezdesetih godina 11. stoljeća ističu se privatna osnivanja samostana, kao što su Zselicszentjakab i Százd (slov. Sazdice), a kralj Gejza I. osnovao je novi samostan u mjestu Garamszentbenedek (slov. Hronský Beňadik, njem. Sankt Benedikt). ${ }^{19} \mathrm{Uz}$ ime svetog Ladislava tradicija veže osnivanje više benediktinskih samostana, od kojihje međutim uvjerljivo razjašnjena samo povijestnastanka samostana u Somogyváru. ${ }^{20}$ Od biskupskih crkava novo su središte dobile biharska i kaločka, prva u Varadinu (mađ. Várad, kasnije Nagyvárad, danas Oradea u Rumunjskoj), a potonja u Baču (mađ. Bács), ${ }^{21}$ dok je u Zagrebu osnovana nova biskupija. ${ }^{22}$ Nesumnjivo je nova pojava razvoj kaptola, dijelom kroz pretvaranje kaptolskih samostana prethodno nastalih $\mathrm{u}$ biskupskim sjedištima u stolne kaptole $\mathrm{u}$ kasnijem smislu riječi, ${ }^{23}$ a dijelom kroz osnutak novoga zbornog kaptola u Titelu. ${ }^{24}$ Također, kanonizacija iz 1083. bila je barem isto toliko politički koliko i crkveni događaj. ${ }^{25}$

Druga polovina 11. stoljeća prvo je razdoblje kada se u našim izvorima pojavljuju podaci o etničkim odnosima u zemlji. U doba svetog Stjepana samo jedan zakon koji spominje "goste" (hospites) ${ }^{26}$ upućuje na činjenicu da u zemlji žive i nemađarske etničke skupine, a ni mlađi izvori o tom razdoblju ne obiluju sličnim naznakama. ${ }^{27}$ Suprotno tomu, u zakonima sačuvanima pod imenom svetog

18 Sažeti prikaz crkvene politike Svetog Ladislava vidi u György Györffy, A “lovagszent" uralkodása (1077-1095) [Vladavina "viteškog sveca"], Történelmi Szemle, sv. 20, Budapest 1977., str. 547-554.

19 1061.: DHA 1, str. 171-174, (oko 1067.): str. 182-185., 1075.: DHA 1, str. 204-218.

20 1091.: DHA 1, str. 266-268.

21 György Györffy, Az Árpád-kori Magyarország történeti földrajza [Povijesni zemljopis Ugarske u doba Arpadovića], sv. 1-4, Budapest 1963. - 1998., sv. 1, str. 682-685, 210-212.

22 Tamás Körmendi, A zágrábi püspökség alapítási éve [Godina utemeljenja zagrebačke biskupije], u: "Köztes-Európa" vonzásában. Ünnepi tanulmányok Font Márta tiszteletére [Privučena srednjoistočnom Europom. Svečani zbornik radova u čast Márte Font], ur. Dániel Bagi - Tamás Fedeles - Gergely Kiss, Pécs 2012., str. 329-341.

23 László Koszta, Székeskáptalanok és kanonokjaik Magyarországon a 12. század elejéig [Stolni kaptoli i njihovi kanonici u Ugarskoj do početka 12. st.], Acta Universitatis Szegediensis de Attila József nominatae. Acta Historica, sv. 103, Szeged 1996., str. 67-81.

24 Između 1077. - 1095.: DHA 1, str. 309. Usp. Gábor Thoroczkay, A Szent Bölcsesség egyháza. A titeli társaskáptalan története a kezdetektől a XIV. század közepéig [Crkva Svete Mudrosti. Povijest titelskog zbornog kaptola od početaka do sredine 14. stoljeća], Fons, sv. 21, Budapest 2014., str. 331-350.

25 Gábor Klaniczay, Az uralkodók szentsége a középkorban. Magyar dinasztikus szentkultuszok és európai modellek [Vladarska svetost u srednjem vijeku. Kultovi ugarskih dinastičkih svetaca i europski modeli], Budapest 2000., str. 114-122.

26 Sancti Stephani decretorum liber primus, c. 24 (Závodszky, Törvények és zsinati határozatok, str. 148, LMKH, str. 6).

27 Primjerice, u rijetke iznimke spada tradicija kraljevskih hospesa iz Szatmára (Satu Mare) zabilježena 1230. po kojoj su se njihovu predci na nagovor kraljice Gizele nastanili na svom mjestu stanovanja, vidi: Codex diplomaticus Hungariae ecclesiasticus ac civilis, sv. 1-11, prir. Georgii Fejér, Budae 1829. 1844., sv. 3/2, str. 211-212 (Magyar Nemzeti Levéltár Országos Levéltára, Diplomatikai Levéltár 90749.). Provjera istinitosti vijesti nije moguća, no njezina točnost nije nemoguća, usp. Attila Zsoldos, Az Árpádok és asszonyaik. A királynéi intézmény az Árpádok korában [Arpadovići i njihove supruge. Kraljice u doba Arpadovića], Budapest 2005., str. 47-48. 
Ladislava pojavljuju se Židovi, ${ }^{28}$ “Talijani"29 i "Ismaelićani” čiji spomen ukazuje na njihovu etničku različitost naznakom religijske zasebnosti, ${ }^{30}$ dok se u poveljama iz tog razdoblja u više prigoda susrećemo s Pečenezima. ${ }^{31}$ Od spomenutih etničkih skupina, kod Židova i “Ismaelićana” može se dokazati, ${ }^{32}$ a kod Pečenega opravdano pretpostaviti ${ }^{33}$ da su njihovi predstavnici pridonijeli etničkoj raznolikosti zemlje već u doba svetog Stjepana. Jedino o “Talijanima" postoje raspoloživi podatci koji bi mogli biti pogodni za pretpostavku da su se skupine gore navedena naziva, koje govore neki od novolatinskih jezika ${ }^{34} \mathrm{u}$ Ugarskoj nastanile - barem $\mathrm{u}$ većem broju zapravo tek sredinom 11. stoljeća. Međutim, što se tiče bližeg razdoblja, u literaturi

28 Sancti Ladislai regis decretorum liber primus, ch. 10, 26 (Závodszky, Törvények és zsinati határozatok, str. 159-160, 162; LMKH, str. 57, 59). Vidi i: András Kubinyi, A magyarországi zsidóság története a középkorban [Povijest ugarskih Židova u srednjem vijeku], Soproni Szemle, sv. 49, Sopron 1995., str. 2-27, Gyula Kristó, Nem magyar népek a középkori Magyarországon [Nemađarski narodi u srednjovjekovnoj Ugarskoj], Budapest 2003., str. 179-183.

29 Sancti Ladislai regis decretorum liber primus, c. 31 (Závodszky, Törvények és zsinati határozatok, str. 163, LMKH, str. 59).

30 Sancti Ladislai regis decretorum liber primus, c. 9 (Závodszky, Törvények és zsinati határozatok, str. 159; LMKH, str. 57). Usp. primjerice, općenito János Karácsonyi, Kik voltak s mikor jöttek hazánkba a böszörmények vagy izmaeliták? [Tko su bili i odakle su došli u našu domovinu Böszörmények ili Ismaelićani?], Budapest 1913., Jenő Szücs, Két történelmi példa az etnikai csoportok életképességéról. Magyarságkutatás. A Magyarságkutató Csoport évkönyve [Dva povijesna primjera održivosti etničkih grupa. Istraživanja mađarstva. Godišnjak istraživačke skupine za proučavanje mađarstva], prir. Gyula Juhász, Budapest 1987., str. 11-27, Kristó, Nem magyar népek, str. 41-54.

31 Oko 1067.: DHA 1, str. 183-184, 1075.: DHA 1, str. 214, 1086.: DHA 1, str. 251, 1091.: DHA 1, str. 268.

32 O Židovima vidi primjerice Sámuel Kohn, Héber kutforrások és adatok Magyarország történetéhez [Hebrejski izvori i podaci za ugarsku povijest], Budapest 1881. [reprint: Budapest 1990.], str. 18-19, o Židovima i Ismaelićanima, vidi Mihály Kmoskó, Mohamedán írók a steppe népeiről [Muslimanski pisci o stepskim narodima], Földrajzi irodalom, sv. 1/2, ur. István Zimonyi, Budapest 2000., str. 242, usp. i Kristó, Nem magyar népek, str. 41-44, 180. Nóra Berend, A kereszténység kapujában. Zsidók, muszlimokés "pogányok" a középkori Magyar Királyságban 1000 k.-1300 k. [Na vratima kršćanstva. Židovi, muslimani i "pogani" u srednjovjekovnom Ugarskom kraljevstvu, o. 1000. - o. 1300.], Máriabesnyő 2012.

33 P. magistri, qui Anonymus dicitur, gesta Hungarorum, c. 57., prir. Aemilius Jakubovich - Desiderius Pais, u: SRH 1, str. 116-117, Chronici Hungarici compositio saeculi XIV., c. 53. (SRH 1, str. 303), Simonis de Keza gesta Hungarorum, c. 94, prir. Alexander Domanovszky, u: SRH 1, str. 192. Usp. György Györffy, Besenyők és magyarok [Pečenezi i Mađari], u: Isti, A magyarság keleti elemei [Istočnjački elementi Mađarstva], Budapest 1990., str. 109-110; Zoltán Kordé, A magyarországi besenyők az Árpád-korban [Ugarski Pečenezi u doba Arpadovića], Acta Universitatis Szegediensis de Attila József nominatae. Acta Historica, sv. 90, Szeged 1990., str. 5-8; Kristó, Nem magyar népek, str. 69-70.

34 Sažetak vidi primjerice u Mihály Auner, Latinus, Századok, sv. 50, Budapest 1916., str. 28-41; Géza Bárczi, A középkori vallon-magyar érintkezésekhez [O srednjovjekovnim dodirima Mađara i Valonaca], Századok, sv. 71, Budapest 1937., str. 399-416; Géza Bárczi, A magyar nyelv francia jövevényszavai [Riječi koje su u mađarski došle iz francuskog jezika], Budapest 1938., str. 3-9; Albin Balogh, Németek és franciák Szent István korában a magyar fővárosban [Nijemci i Francuzi u ugarskom glavnom gradu u doba sv. Stjepana], Katolikus Szemlei, sv. 58, Budapest 1944., str. 44-46; László Zolnay, Az esztergomi latinusokról [O ostrogonskim Latinima], u: Annales Strigoniensis. Esztergom évlapjai. Az esztergomi múzeumok évkönyve, sv. 1, ur. László Zolnay, Budapest 1960., str. 15-167, György Székely, A székesfehérvári latinok és vallonok a középkori Magyarországon [Stolnobiogradski Latini i Valonci u srednjovjekovnoj Ugarskoj], u: Székesfehérvár évszázadai II. Középkor [Stolnobiogradska stoljeća II. Srednji vijek], ur. Alán Kralovánszky, Székesfehérvár 1972., str. 45-72; Kristó, Nem magyar népek, str. 167-177. 
se spominje druga polovina četrdesetih godina 11. stoljeća, ${ }^{35}$ što znači da se ni pojava prvih skupina "Talijana" u Ugarskoj ne može povezati s dobom svetog Ladislava utvrđenim po gore spomenutim načelima, no opravdano možemo računati s tim da je do posljednje trećine 11. stoljeća njihov broj toliko porastao da se njihovim pitanjima izravno bavilo Kraljevsko vijeće. ${ }^{36}$

U društvu u doba svetog Ladislava izvan svake sumnje nastaju određene novosti. Njih je već prikazala i opisala moderna društvenopovijesna sinteza. Bit promjene sastoji se u tome da se prethodno jedinstveni pojam "slobode" do doba svetog Ladislava raspao i slijedom toga i društvena skupina slobodnjaka i ona "slugû" tvore složeniju sliku koncem 11. stoljeća nego u desetljećima nakon prijelaza u drugo tisućljeće. ${ }^{37}$ Među slobodnjacima isticala se skupina odličnika koja se otad nazivala "plemićima". Sam izraz "plemić" (nobilis) prvi se put pojavljuje u izvoru koji poznajemo kao III. zakon svetog Ladislava, ${ }^{38}$ no javlja se i u odredbama drugih dvaju zakona vezanih uz ime svetog Ladislava. ${ }^{39}$ Njihova analiza rasvjetljuje činjenicu da je riječ o skupini s privilegijama naspram običnih slobodnjaka, skupini odličnika koju je jedan od zakona svetog Stjepana još nazivao uporabom opisa "viši u pogledu rođenja i časti" (maiores natu et dignitate). ${ }^{40}$

U slučaju slugu promjena se zapravo sastoji $\mathrm{u}$ tome da dok je $\mathrm{u}$ vrijeme svetog Stjepana bio poznat isključivo oblik oslobađanja slugu koji oslobođenima daje pravni status rođenih slobodnjaka, ${ }^{41}$ sada se pojavljuje tip statusa u kojem sloboda više nije potpuna, već se veže za uvjet, ${ }^{42}$ na taj način udarivši temelje zamršenog svijeta društva slugu, tako svojstven dobu Arpadovića. Oba se društvenopovijesna razvoja, ovisno

35 György Györffy, A székesfehérvári latinok betelepülésének kérdése [Pitanje useljavanja stolnobiogradskih Latina], u: Székesfehérvár évszázadai, str. 37-42; Péter Tóth, A vallonok legkorábbi betelepülése Magyarországra [Najranije useljavanje Valonaca u Ugarsku], u: Hermann Ottó Múzeum Évkönyve, sv. 46, ur. László Veres - Gyula Viga, Miskolc 2007., str. 543-549.

36 Sancti Ladislai decreta liber primus, c. 31 (Závodszky, Törvények és zsinati határozatok, str. 163, LMKH, str. 59).

37 Ilona Bolla, A jogilag egységes jobbágyosztály kialakulása Magyarországon [Formiranje pravno ujednačene klase kmetova u Ugarskoj], Budapest 1983., str. 37-39, 40-43.

38 Sancti Ladislai decreta liber tertius, c. 2, 12 (Závodszky, Törvények és zsinati határozatok, str. 173, 176177, LMKH, str. 18, 21).

39 Sancti Ladislai regis decretorum liber secundus, c. 9, 11 (Závodszky, Törvények és zsinati határozatok, str. 168-169, LMKH, str. 14), Sancti Ladislai regis decretorum liber primus, c. 41 (Závodszky, Törvények és zsinati határozatok, str. 165, LMKH, str. 61).

40 Sancti Stephani decretorum liber primus, c. 21 (Závodszky, Törvények és zsinati határozatok, str. 147, LMKH, str. 5). O problemu vidi Attila Zsoldos, Nemes és nemzetség [Plemić i rod], u: Magyar történettudomány az ezredfordulón. Glatz Ferenc 70. születésnapjára [Mađarska povijesna znanost na smjeni tisućljeća. U povodu 70. rođendana Ferenca Glatza], ur. Lajos Gecsényi - Lajos Izsák, Budapest 2011., str. 421-425.

41 Bolla, A jogilag egységes jobbágyosztály, str. 31-32.

42 Sancti Ladislai regis decretorum liber primus, c. 30.: qui [...] pro animarum salute libertate mancipati fuerint, eo tenore tamen, ut ecclesie serviant. Závodszky, Törvények és zsinati határozatok, str. 162, LMKH, str. 59. Vidi: Sancti Ladislai regis decretorum liber primus, c. 27 (Závodszky, Törvények és zsinati határozatok, str. 162, LMKH, str. 59). 
o nastanku zakona sačuvanih pod imenom svetog Ladislava, mogu vezati za doba svetog Ladislava ili doba Ladislavove vladavine, koja obuhvaća kraće razdoblje.

I na koncu, kao svojevrsnu nadoknadu za možda pretjerano grubu skicu gornjeg pregleda, o jednom ću pitanju govoriti podrobnije. U skladu s najavom govorit ću o dukatu (herceštvu): pokušat ću iz poznatih izvora identificirati jedan dosad nepoznat dio povijesti te institucije. To sam pitanje odabrao upravo zbog toga što je u određenoj vezi s jednim poglavljem zajedničke hrvatsko-mađarske prošlosti.

Na temelju raspoloživih podataka geografski doseg dukata ne može se jasno odrediti. Sigurno je to da je Bihar bio dio te upravne jedinice već u prvom razdoblju njezina postojanja, to jest u vrijeme kneževanja kralja Bele I. ${ }^{43}$ Nesumnjivo je da se 1074. dukat protezao i na područje Njitre. No Njitru uz dukat veže jedino opis bitke kod Mogyoróda 1074., ${ }^{44}$ što samo po sebi, s obzirom na povijest 11. stoljeća, siromašnog izvorima, ne bi dalo razloga za sumnju. Ono, pak, što daje razloga za to jest činjenica da se u našim izvorima o prijašnjim i kasnijim razdobljima kneževi koji su na neki način vezani za dukat redom pojavljuju u vezi s drugim dijelom zemlje.

Bela, otac svetog Ladislava osnovao je samostan u Szekszárdu, dakle na području Pečuške biskupije, i tamo je i pokopan. ${ }^{45}$ Premda se kao vrijeme osnutka inače spominje 1061. godina, ${ }^{46}$ ona zapravo ne označava nastanak povelje o osnivanju, već fragmentarno poznate povelje tada već kralja Bele I. koja popisuje prava samostana, ${ }^{47}$ pa je dakle samostan osnovan nekad prije, po svemu sudeći u vrijeme kneza Bele. ${ }^{48}$ Do razvoja bliskog odnosa između pečuškog biskupa Maura i starijeg brata svetog Ladislava, kneza Gejze - o kojem svjedoči legenda o pustinjacima Andriji i Benediktu kanoniziranima 1083., koju je napisao upravo Maur ${ }^{49}$ - jedini posjet kneza Pečuhu zacijelo nije bio dostatan, čini se opravdanijim pretpostaviti dulju vezu, koja bi se, međutim, mnogo prije nego u Njitri odvijala u Pečuhu, gdje je Maur bio biskup od 1036. godine..$^{50}$ Ta se dva podatka mogu smatrati tek zanimljivošću vrijednom

43 Chronici Hungarici compositio saeculi XIV., c. $92-93$ (SRH 1, str. 353-354, 357).

44 Chronici Hungarici compositio saeculi XIV., c. 121 (SRH 1, str. 389-390). Prijašnja mišljenja historiografa od početka su smatrala da je i okolica Njitre dio dukata, vidi primjerice Györffy, A magyar nemzetségtől a vármegyéig, str. 49, Kristó, A XI. századi hercegség, str. 66, László Koszta, A nyitrai püspökség létrejötte (Nyitra egyháztörténete a 9-13. században) [Uspostava biskupije u Njitri (Crkvena povijest Njitre od 9. do 13. stoljeća)], Századok, sv. 143, Budapest 2009., str. 269-270, 280-293.

45 Chronici Hungarici compositio saeculi XIV., c. 96 (SRH 1, str. 360).

46 Vidi primjerice Beatrix F. Romhányi, Kolostorokés társaskáptalanok a középkori Magyarországon [Samostani i zborni kaptoli u srednjovjekovnoj Ugarskoj], Budapest 2000., str. 61-62 (s ranijom literaturom o tom pitanju); Gergely Kiss - Gábor Sarbak, Szerzetesi intézmények [Monastičke ustanove], u: A Pécsi Egyházmegye története I. A középkor évszázadai (1009-1543) [Povijest pečuške biskupije I. Srednjovjekovna stoljeća (1009. - 1543.)], ur. Tamás Fedeles - Gábor Sarbak - József Sümegi, Pécs 2009., str. 352.

47 DHA 1, str. 166-168.

48 Usp. György Györffy, István király és müve [Kralj Stjepan i njegovo djelo], Budapest 1977., str. 326.

49 Vita sanctorum heremitarum Zoerardi confessoris et Benedicti maritis a beato Mauro episcopo Quinecclesiastensi [sic] descripta, c. 3, prir. Emericus Madzsar, u: SRH 2, str. 360.

50 Attila Zsoldos, Magyarország világi archontológiája 1000-1301 [Svjetovna arhontologija Ugarske 1000. 1301.], Budapest 2011., str. 94. 
pozornosti prisjetimo li se da je nakon ukidanja dukata sin - oslijepljen kao dijete, poslije kralj Bela II. - kneza Álmosa, bratića svetog Ladislava, nakon bijega svoga oca, također oslijepljenog Álmosa, u Bizant, ${ }^{51}$ pronašao utočište upravo na području Pečuške biskupije, u samostanu u Pécsváradu; a potom, nakon što su umiješani velikaši otkrili pred kraljem Stjepanom II. - koji nije imao djece -, sinom kralja Kolomana koji je dao oslijepiti kneževe Álmosa i Bélu, da se slijepi knez Bela skriva u Ugarskoj - vladar je imenovao Tolnu koja se nalazi u pečuškoj dijecezi kao boravište kneza, i tamo mu je osigurao dostojanstven život..52 Dakle, dovoljno je jasno da su prva dva naraštaja vladara dukata - koji su poslije postali kraljevi Bela I. i Gejza I. - bila u uistinu tijesnoj vezi s Pečuhom i područjem pečuške dijeceze, i upravo je ta nekadašnja veza u slučaju kneza Bele, sina Álmosa lišenog dukata, oživjela nakon nekoliko desetljeća.

Unatoč siromašnim općim izvorima o 11. stoljeću pruža se mogućnost i za dodatnu potkrepu. Prema našim je saznanjima knez Álmos osnovao dvije crkvene ustanove: u Meszesu je osnovao benediktinski samostan, ${ }^{53}$ a u Dömösu zborni kaptol. ${ }^{54}$ Prvi je smješten u kraju koji pripada županiji Közép-Szolnok (Srednji Szolnok), ${ }^{55}$ stoga bi bilo teško osporiti da ga je Álmos osnovao neke od godina u kojima je još vladao dukatom, a suprotno tomu, Dömös nikada nije pripadao području dukata, no sigurno je da je Álmos tu osnovao prepozituru kad ga je brat Koloman već lišio dukata. Knez David, sin Andrije I., nikada nije bio vladar dukata, te je oko 1089./1090. darovao posjed i služinčad samostanu u Tihanyu koji je njegov otac bio osnovao na području Vesprimske biskupije. ${ }^{56}$ Dakle, možemo utvrditi ne samo to da su prije 1064. kneževi koji posjeduju dukat bili u izrazito živoj vezi s pečuškom dijecezom nego $i$ to da se ista veza uopće ne može dokazati kod kneževa iz 11. stoljeća koji nisu - ili, poput Álmosa, više nisu - stajali na čelu dukata.

Podatcima koji, premda su međusobno nepovezani, upućuju u istom smjeru, to jest koji ukazuju na odnos između kneževa koji posjeduju dukat i pečuške dijeceze, golemu važnost pridaje ono što znamo o pomirenju kralja Solomona i njegova nećaka, kneza Gejze 1064. godine. Sporazum dvojice rođaka uslijedio je "na

51 Usp. Bullae Bonifacii IX. P. M. Pars altera 1396-1404., Monumenta Vaticana Historiam Regni Hungariae illustrantia. Series prima. Tomus quartus, Budapest 1889., str. 579.

52 Chronici Hungarici compositio saeculi XIV., c. 157: Disposuerat eum [sc. Bela ducem] rex [sc. rex Stephanus II.] vivere in Talua et dabantur ei regalia stipendia (SRH 1, str. 443).

53 1165.: Codex diplomaticus domus senioris comitum Zichy de Zich et Vasonkeő, sv. 1-12, prir. Iván Nagy et al., Budapest 1871. - 1931., sv. 1, str. 2. Sažeti prikaz povijesti samostana u Meszesu, vidi Pongrác Sörös, Az elenyészett bencés apátságok (A pannonhalmi Szent-Benedek-rend története [Izumrle benediktinske opatije (Povijest pannonhalmskog benediktinskog reda)], sv. 12/B, Budapest 1912., str. 449-450.

54 Chronici Hungarici compositio saeculi XIV., c. 148: Dux autem [sc. Almus] construxit monasterium de Demes (SRH 1, str. 427). O osnutku i ranoj povijesti prepoštva u Dömösu, vidi Gábor Thoroczkay, A dömösi prépostság története alapításától I. Károly uralkodásának végéig [Povijest dömöške prepozitura od uspostave do kraja vladavine Karla I.], Fons, sv. 19, Budapest 2012., str. 409-433.

55 F. Romhányi, Kolostorok és társaskáptalanok, str. 44.

56 Oko 1089. - 1090.: DHA 1, str. 264-265. 
blagdan mučenika svetog Fabijana i Sebastijana [...] pred licem Ugarske u Győru" (in festo [...] Sanctorum Fabiani et Sebastiani martirum [...] coram Hungaria in Geur), ${ }^{57}$ to jest politički sporazum sklopljen 20. siječnja slijedili su reprezentativni vanjski rituali, a mjesto događanja bio je dio zemlje gdje je boravio kralj. Međutim, priča se u kronikama nastavlja tako da su Uskrs - to jest veliki blagdan koji po crkvenom kalendaru slijedi odmah nakon toga, a padao je na dan 11. travnja 1064. - kralj i knez Gejza slavili “zajedno s cijelim dvorom [...] u Pečuhu. Ovdje se na dan Uskrsa, u nazočnosti velikodostojnika zemlje, od ruke kneza Gejze okrunio kralj Solomon, te je svečano odveden u kraljevsku baziliku svetog Petra, apostola nad apostolima, da sluša misu", te je "cijela crkvena zajednica Mađara" (congregatio Hungarorum) slavila mir. ${ }^{58}$ Dakako, spomenuta krunidba nije bila istovjetna s obredom kraljevske inicijacije, smatrala se svojevrsnim očitovanjem kojim se željelo izraziti to da je knez Gejza spreman priznati Salomona kao kralja. Obred je, pa zacijelo i sam odabir mjesta događanja, očito bio simbolična značaja. No uočljivo je da odabir nije pao na Stolni Biograd, koji je tada već tradicionalno bio mjesto krunidbi, ni na drugu kraljevsku prijestolnicu, Ostrogon, pa čak ni na grad kaločkog nadbiskupa, vrhovnog svećenika Deziderija koji je po svemu sudeći odigrao ključnu ulogu u nastanku mira, već na Pečuh. Teško je misliti na drugo doli na ovo: u pozadini odluke stajala je nakana da knez proglasi svoje podaništvo pred zakonitim kraljem i u vlastitom dijelu zemlje, to jest $\mathrm{u}$ dukatu. To tumačenje potkrepljuje osobita okolnost da Gejza nije postavio krunu na Salomonovu glavu u pečuškoj bazilici, već pred njom, pa je krunidbu zacijelo vidjelo mnogo više ljudi nego da se sve to odvilo unutar zidova katedrale. Možda bi bilo pogodnije održati svečanost u Biharu, koji međutim tada, svega nekoliko godina nakon osnutka mjesne biskupije, vjerojatno nije bio spreman za organizaciju tako velikog događaja. Dakle, imamo razloga, i to opravdanoga, smatrati da se Pečuh 1064. godine - a očito i prije - nalazio na području dukata, iz čega nužno proizlazi da je županija Baranja, kao i vjerojatno gotovo cijelo područje Pečuške biskupije, u to vrijeme pripadala dukatu. ${ }^{59}$ Dakle, dukat se izvorno protezao na Jugoistočno Zadunavlje - i na pripadajuća prekodravska područja - te na Bihar i njegovu okolicu s druge strane rijeke Tisze. Međutim, poslije se taj poredak podjele zemlje promijenio: nakon 1064. više nam podataka koji bi povezivali kneževe na čelu dukata i područje pečuške dijeceze, no pojavljuje se, uz Bihar, okolica Njitre. Objašnjenje je najvjerojatnije $u$ tome da su Solomon i Gejza zamijenili područja, slijedom čega je okolica Njitre preuzela ulogu Pečuha i okolice, a u to je vrijeme

57 Chronici Hungarici compositio saeculi XIV., c. 97 (SRH 1, str. 362).

58 Chronici Hungarici compositio saeculi XIV., c. 97: simul cum plena curia Quinqueecclesiis celebraverunt. Ubi rex Salomon ipso die Pasce assistentibus regni proceribus per manus Geyse ducis honorabiliter est coronatus et in regiam Beati Petri principis apostolorum basilicam ad audiendam missam gloriose deductus (SRH 1, str. 362).

59 Na to da je županija Baranja vjerojatno pripadala dukatu - na temelju drugog argumenta i manje izričito - mislio je već i Györffy György (Történeti földrajz, sv. 1, str. 252). 
vjerojatno i središte dukata preneseno na biharska područja. Kao vrijeme potonje promjene najvjerojatnije možemo uzeti u obzir razdoblje skladne suradnje kralja i kneževa, dakle drugu polovinu šezdesetih godina 11. stoljeća. O razlozima zamjene područja nemamo informacija, no slobodno možemo smatrati da je možda kralj Salomon bio inicijator. Naime, izvorno područje dukata bilo bi omogućilo da u slučaju pogoršavanja odnosa između kralja i kneževa Gejza i njegova braća dobiju pomoć ne samo iz Poljske, koja je iz Bihara bila veoma dostupna, nego i - preko hrvatskog braka njihove sestre - s juga, na što je pohod u Hrvatsku koji su Solomon i kneževi zajedno vodili oko 1066./1067. vjerojatno skrenuo pozornost kralja i njegovih savjetnika. ${ }^{60}$ Ako je doista bilo tako, zamjena područja do izvjesne mjere bila je već svojevrsna priprema za kasnije razdoblje, u kojem je doista izbio sukob.

Preveli: Lea Kovács i dr. György Lukács B.

60 Chronici Hungarici compositio saeculi XIV., c. 99. (SRH 1, str. 363-364). Usp. Mór Wertner, Az Árpádok családi története [Povijest dinastije Arpadovića], Nagybecskerek 1892., str. 160-167, Makk, Magyar külpolitika, str. 99; Dénes Sokcsevits, Horvátország a 7. századtól napjainkig [Hrvatska od 7. st. do naših dana], Budapest 2011., str. 81. Vidi i hrvatsko izdanje: Dinko Šokčević, Hrvatska od stoljeća 7 . do danas, Zagreb 2016., str. 53. 
Attila Zsoldos

\title{
Hungary in the Era of St. Ladislas
}

\author{
Summary
}

The study outlines the picture of the Kingdom of Hungary in the time of King Ladislas I (1077-1095), but starting back to the beginning of his advent on the political scene (1063), which is justified by the fact that he already at that time played a significant role in shaping the fate of Hungary.

The first half of the study looks at the general characteristics of the country. In addition to the issues of the king and his court, secular and ecclesiastical administration, issues of legislation, and the transformation of the ethnic relations of the country, the review covers new phenomena in the society of the age. The latter include the emergence of nobility as well as that of conditional freedom connected to it.

The second half of the study deals with the institution of the ducatus, establishment of which reflects a characteristic form of the division of power within the ruling family in the second half of the 11th century. According to previous ideas, the area of the ducatus in the earlier period spread in the vicinities of Bihor and Nitra. The study argues that the ducatus originally covered area from Southeast to Transdanubia - and to it associated areas on the other side of the Drava river - as well as Bihar and its environs in the areas on the other side of the Tisza river.

In the 1070s, the Nitra region replaced Pécs and its surroundings, and the centre of the ducatus may have moved to the Bihar area at that time. This change might be initiated by King Solomon (1063-1074). The original territory of the ducatus would have therefore made it possible for Prince Géza and his brothers to receive help not only from Poland, easily accessible from Bihar, but also, through the Croatian marriage of their sister, from the south. However, on the perils of such arrangement for the king, the campaign in Croatia, which they and the king led jointly 1066-1067, may have brought the attention of the king and his advisers and cause further tensions.

Key words: Ladislas I (St Ladislas), the Árpád dynasty, political history, the eleventhcentury history, Nitra, Bihar, Pécs, ducatus (duchy) 